\title{
Editorial
}

\section{Brand new territory: Leadership, practice and research agenda}

\author{
Journal of Brand Management (2009) 17, 163-164. doi:10.1057/bm.2009.34
}

The Academy of Marketing's Brand Special Interest Group held its 5th International Conference at Clare College, Cambridge University, UK, from 1-3 September 2009. The theme of the conference, 'Branding and Society: Social, Cultural and Financial Impact of Brands in the 21st Century' captures new horizons, competitive environment and the continuing diffusion of brand strategy across sectors. It also highlights the market experience in which: (i) brands are increasingly reconstructing cultural and economic realities; and (ii) brands are the product of creativity and imagination - all of which appear to be influenced by contemporary articulations of symbols and simulacrum., ${ }^{1,2}$

In all, there were 137 delegates from 18 European countries, as well as from China, Malaysia, Australia, South Africa, Canada and the United States. We had a robust cross-section of full-time academics, practitioners and nearly 40 doctoral researchers. The first session was opened by Professor Tim Ambler, London Business School, who gave a no-nonsense perspective on 'Brand Fundamentalism'. His Plenary Address set the tone for the conference. In association with the Journal of Brand Management's Editorial team, the conference was proud and delighted to honour Tim Ambler's contributions in the areas of advertising and decisions-making, neuromarketing $^{3-5}$ and, notably, on Marketing Metrics. On behalf of the Academy of Marketing's AM Brand SIG, Tim was pre- sented with a lifetime achievement award at the conference dinner by Professor Caroline Tynan, Vice President of the Academy of Marketing. Our keynote speakers, who were all 'brand names', included: Professor Russell Abratt, from Nova South Eastern University, USA ('Twenty Years On: Aligning Corporate Identity, Corporate Branding and Corporate Reputation'); Professor Mary-Jo Hatch, Emerita, University of Virginia and Copenhagen Business School ('The Pragmatics of Branding: An application of Dewey's Theory of Aesthetic Expression'); and Professor Bernd Schmitt, Columbia Business School ('Managing the Brand Experience'). ${ }^{6}$ These were supported by the following excellent brand practitioners: David Radford, Director of Marketing for LV = ('Consumer Relationships with brands'); Nick Cooper, Senior Vice President, Millward Brown Optimor, United Kingdom and Europe; and Robert Jones, Head of New Thinking at Wolff Olins and Lecturer in Brand Leadership at the University of East Anglia ('Brand Next'). Dr Ray Holland from the Brunel School of Engineering led a 'Pecha-Kucha Session on the need for rapprochement between engineering, design and brand marketing'.

The conference was drawn to a close by Tim Ambler who chaired an expert panel that was made up of all the guest speakers. In collaboration with the audience of delegates, he was able to identify a number 
of important themes for future research from a long list of eight topics:

1. Employee Engagement and Relationships between employees, management and brands in a human resource context.

2. The Neuroscience of marketing and brands.

3. The changing marketing context of environmentalism, green design, eco brands and CSR-related value propositions.

4. How academics can work more closely with practitioners to disseminate research.

5. Small and medium enterprise, philanthropic, not for profit and fourth way branding.

Other key topics that underpinned successful brand value propositions in relation to social media environment were also highlighted. These included: the role of technological innovation and advances in data analytic in capturing customer behaviour towards brands; analysis of user generated content; and analyzing point of experience behavioural data such as unstructured semantic information and their impacts on brand reputation.

Two themes emerged from the conference:

1. The need for inter-disciplinary rapprochement with other areas such as engineering, design and innovation; neuron science and the emerging areas of data analytics; and the urgent need make our work rigorous and even more relevant to the 'real-world'.

2. The second theme is that of determining how best to direct our research on those hitherto under-researched issues, and their impacts and relationships on emerging fields in the dynamic areas of brand marketing.
The team from the Special Interest Group (SIG) (Dr Temi Abimbola, Warwick Business School; Dr Myfanwy Trueman, Bradford University School of Management; Dr Ming Lim, Leicester Business School; Professor TC Melewar, School of Management and Law, Zurich University of Applied Sciences; Dr Stuart Roper, Manchester Business School; Dr Francisco Guzman, University of North Texas and ESADE, Spain; Dr Oriol Iglesias, ESADE, Barcelona; and Dr Jatinder Singh, ESADE) are all busy reviewing and editing the articles submitted to the conference.

We urge colleagues to reflect on the impact of these advances in both academic research and practice-based investigations. The Journal of Brand Management welcomes rigorous, thought-provoking and relevant articles on these themes and their emergent topics.

\section{REFERENCES}

(1) Abimbola, T. and Kocak, A. (2007) Brand organization identity and reputation: SMEs as expressive organization: A resources-based perspective. Qualitative Market Research: An International Journal 10(4): 416-430.

(2) Guzman, F. and Abimbola, T. (2009) The power of brands as intangible asserts. Journal of Product and Brand Management 18(5): 324-325, http://www.emeraldinsight.com/Insight/viewContainer.do;jsessionid $=20 \mathrm{D} 971 \mathrm{~F} 769767376 \mathrm{AAB}$ 9012A107CA0E7? containerType $=$ Issue\&container $\mathrm{Id}=15001903$.

(3) Ambler, T. (2000) Persuasion, pride and prejudice: How ads work. International Journal of Advertising 19: 299-315.

(4) Ambler, T. (2004) Salience and choice: Neural correlates of shopping decisions. Psychology \& Marketing 21(4): 247-261.

(5) Ambler, T., Braeutigam, S., Stins, J., Rose, S. and Swithenby, S. (2004) Salience and choice: Neural correlates of shopping decisions. Psychology \& Marketing 21(4): 247-261.

(6) Schmitt, B.H. and Rogers, D.L. (2008) Handbook on Brand and Experience Management. Cheltenham, UK: Edward Elgar.

Temi Abimbola Joint Editor-in-Chief 